\title{
Awake Endospine Disektomi pada Pasien Lumbar Spinal Stenosis karena Hernia Nucleus Pulposus
}

\author{
Nuzulul Widyadining Laras, Himawan Sasongko \\ Departemen Anestesiologi dan Terapi Intensif Fakultas Kedokteran Universitas Diponegoro-RSUP Dr. Kariadi \\ Semarang
}

\begin{abstract}
Abstrak
Lumbar spinal stenosis (LSS) merupakan gejala penyakit yang berhubungan dengan berkurangnya ukuran canalis spinalis vertebra lumbal menyebabkan penekanan saraf yang terletak di dalamnya. Berdasar penyebabnya dibagi jadi dua, kongenital dan degeneratif. Pasien dapat merasakan fase nyeri yang tidak dapat diprediksi dan juga fase stabil tanpa nyeri. Salah satu contoh LSS degeneratif adalah pembengkakan diskus intervertebralis atau HNP. Penyakit HNP merupakan salah satu penyebab dari nyeri punggung bawah dan merupakan salah satu masalah kesehatan yang utama. Prevalensi HNP berkisar antara 1-2 \% dari populasi. Terapi yang dilakukan salah satunya endospine disektomi. Operasi ini dapat dikerjakan dengan general anestesia (GA) atau neuroaksial anestesia (spinal, epidural). GA lebih dipilih karena lebih aman dari komplikasi gangguan jalur nafas. Deksmedetomidine memiliki efek sedasi tanpa risiko depresi respirasi serta memiliki efek analgesi dapat digunakan untuk metode awake endospine pada disektomi. Pada penulisan ini, dilakukan pemilihan teknik anestesi awake untuk mengakomodasi operator untuk menilai respon nyeri dan fungsi motorik pasien saat operasi.
\end{abstract}

Kata kunci: Lumbar spinal stenosis, hernia nucleus pulposus, endospine disektomi, awake anestesi

JNI 2020, 9 (3): 173-82

\section{Awake Endospine Dissectomy in Patient with Lumbar Spine Stenosis caused by Hernia Nucleus Pulposus}

\begin{abstract}
Lumbar spinal stenosis (LSS) are symptoms from degradation canalis spinalis vertebrae's size which pressured nerve inside it. Based on its cause, there are two types of LSS, congenital and degenerative. The patient can experience an unpredictable pain phase as well as a stable phase without pain. Bulging of intervertebralis disc or HNP is one of degenerative LSS. HNP disease is one of the causes of low back pain and is a major health problem. HNP prevalention is 1-2\% from population. One of therapy use to medicate LSS is endospine discectomy. This operation done with general anesthesia (GA) or neuroaxial anesthesia (spinal, epidural). GA preferably used because it caused less side effect like airway obstruction or neural injury. Dexmedetomidine has a sedative effect without the risk of respiratory depression and has an analgesic effect. It can be used to awake endospine methods in dissectomy. In this case report, the writer did awake endospine method to accommodate operator so they could know level of pain and motoric function of patient durante operation.
\end{abstract}

Key words: Lumbar spinal stenosis, hernia nucleus pulposus, endospine dissectomy, awake anesthesia.

JNI 2020, 9 (3): 173-82

This article is licensed under a

Creative Commons Attribution-NonCommercial-ShareAlike 4.0 International License.

CNuzulul Widyadining Laras, Himawan Sasongko (2020) under the CC-BY-NC-SA

license 


\section{Pendahuluan}

Lumbar spinal stenosis (LSS) merupakan istilah kedokteran yang digunakan untuk menjelaskan pasien dengan gejala penyakit yang berhubungan dengan berkurangnya ukuran canalis spinalis vertebra lumbal sehingga menyebabkan penekanan saraf yang terletak di dalamnya. Spinal stenosis dikelompokkan menjadi dua yaitu spinal stenosis primer yang disebabkan oleh kelainan kongenital atau kelainan pertubuhan setelah lahir. Kelompok kedua yaitu spinal stenosis sekunder (stenosis didapat) akibat dari perubahan degeneratif atau konsekuensi dari infeksi lokal, trauma, atau operasi. Penyebab lumbar spinal stenosis yang paling sering adalah akibat proses degeneratif yang lambat dan progresif terutama pada tiga tulang lumbal terbawah. Pasien dapat merasakan fase nyeri yang tidak dapat diprediksi dan juga fase stabil tanpa nyeri. ${ }^{1-4}$

Secara anatomi, LSS degeneratif dapat mengenai kanalis sentralis, lateral, foramina atau kombinasi dari semua lokasi ini. Stenosis kanalis sentral terjadi akibat dari berkurangnya diameter antroposterior, transversal atau kombinasi karena hilangnya tinggi diskus dengan atau tanpa pembengkakan diskus intervertebralis, dan hipertrofi facet joint dan ligamentum flavum. Fibrosis adalah penyebab utama hipertrofi ligamentum flavum dan disebabkan karena akumulasi tekanan mekanik, terutama sepanjang aspek dorsal ligamentum flavum. Transforming growth factor (TGF)- $\beta$ yang dilepas sel endotel menstimulasi fibrosis terutama selama fase awal hipertropi.

Proses yang sama mengurangi tinggi diskus, hipertrofi facet joint (dengan atau tanpa spondilolistesis) dan atau osteofitosis vertebral endplate dapat terjadi pula pada stenosis lateral. Foraminal stenosis dapat terjadi anteroposterior akibat dari kombinasi penyempitan ruang diskus dan pertumbuhan berlebih dari struktur anterior kapsul facet joint. Selain itu, dapat terjadi secara vertikal akibat dari osteofit posterolateral mendesak ke foramen karena anulus fibrosus yang membengkak ke lateral atau herniasi diskus yang menekan akar saraf ke pedikel superior. Foraminal stenosis sering terjadi pada akar saraf karena foramen L5-S1 memiliki rasio area foramen dibanding akar yang lebih kecil. ${ }^{5,6}$ Adanya pembengkakan (bulging) pada diskus intervertebralis inilah yang dimaksud dengan Hernia Nucleus Pulposus (HNP). Hernia adalah protrusi atau penonjolan dari sebuah organ atau jaringan melalui lubang yang abnormal. Nucleus pulposus adalah massa setengah cair yang terbuat dari serat elastis putih yang membentuk bagian tengah dari diskus intervertebralis. Kondisi HNP merupakan suatu gangguan yang melibatkan ruptur annulus fibrosus sehingga nukleus pulposis menonjol (bulging) dan menekan kearah kanalis spinalis. Sinonim HNP antara lain Hernia Discus Intervertebralis, Rupture Disc, Slipped Disc atau Prolapsed Disc. Prevalensi HNP berkisar antara $1-2 \%$ dari populasi. Usia yang paling sering adalah usia 30-50 tahun. Pada penelitian, HNP paling sering dijumpai pada tingkat L4-L5 (titik tumpuan tubuh di L4-L5-S1).

Penelitian oleh Dammers dan Koehler pada 1.431 pasien dengan herniasi diskus lumbalis, memperlihatkan bahwa pasien angka kejadian HNP L3-L4 lebih banyak pada usia tua dibandingkan dengan pasien HNP L4-L5. Penyakit HNP merupakan salah satu penyebab dari nyeri punggung bawah dan merupakan salah satu masalah kesehatan yang utama. ${ }^{7,8}$ Untuk daerah lumbal angka kejadian tertinggi pada L4L5 dan L5-S1 sebesar 90\% dan selebihnya pada daerah L3-L4 HNP pada L1-2 dan L2-3 sangat jarang ditemui, HNP pada lumbal bagian atas sering karena trauma yang berat ${ }^{9}$. Studi populasi di daerah pantai utara Jawa Indonesia didapati insiden $18,2 \%$ pada pria dan $13,6 \%$ pada wanita.

Pada beberapa RS di Jakarta, Yogyakarta dan Semarang insidens berkisar antara 5,4-5,8 \% dan frekuensi terbanyak pada usia 45-65 tahun. Pada penderita dewasa tua, nyeri punggung bawah mengganggu aktivitas sehari-hari pada $40 \%$ penderita dan menyebabkan gangguan tidur pada $20 \%$ penderita akan mencari pertolongan medis, dan $25 \%$ di antaranya perlu rawat inap untuk evaluasi lebih lanjut. ${ }^{9}$ Gejala LSS paling umum adalah klaudikasio neurogenik atau pseudoklaudikasio. Klaudikasio neurogenik 
adalah nyeri di bagian kaki meliputi pantat, paha, hingga telapak kaki. Selain nyeri, pasien juga merasa lelah, berat, lemah dan atau parestesia. Pasien dengan LSS juga mengalami kram kaki nokturnal dan gejala gangguan berkemih. Gejala dapat terjadi unilateral atau bilateral dan simetris. Nyeri meningkat bila ekstensi lumbar dan menurun saat fleksi lumbar. ${ }^{10,11}$

Berbagai pilihan terapi tersedia untuk pasien dengan LSS antara lain terapi konservatif menggunakan obat-obatan analgesik, obat anti inflamasi non steroid, kortikosteroid sistemik atau opioid, terapi fisik dengan latihan dan korset, injeksi epidural dan operasi. Beberapa Teknik operasi digunakan untuk mengobati pasien LSS dan gejala persisten yang tidak dapat dikontrol secara adequate oleh terapi lain. Prosedur paling umum yang dilakukan adalah dekompresif laminektomi. Operasi lain yang dapat diterapkan adalah perkutaneus disektomi, endoskopi disektomi dan nukleoplasti. ${ }^{12,13}$ Endoskopi disektomi dapat dilakukan dengan setting operasi ambulatori menggunakan sedasi sedang atau pengawasan anestesi. Teknik anestesi yang paling umum digunakan adalah general anestesi (GA/anestesi umum), tetapi bisa juga menggunakan anestesi neuroaksial (spinal atau epidural). Penggunaan GA yang paling sering bukan berdasarkan bukti ilmiah tetapi karena pilihan dokter bedah saraf karena lebih nyaman, sedangkan neuroaksial tidak sering digunakan karena pasien tersedasi dalam posisi pronasi (tengkurap) berhubungan dengan komplikasi jalan nafas serta kemungkinan luka saraf jika pasien bangun tiba-tiba bergerak atau bergeser selama prosedur dilakukan. ${ }^{14}$ Pemilihan teknik anestesi awake yang kurang lazim untuk endoskopi disektomi dilakukan karena dokter bedah saraf perlu menilai respon nyeri pasien saat operasi, pengerjaan disektomi disesuaikan dengan nyeri yang masih dirasakan atau tidak.

Oleh karena itu, dilakukan anestesi awake dimana pasien dengan sedasi ringan dan analgetik adekuat sehingga sadar saat ditanyai apakah masih nyeri tapi tidak merasakan nyeri saat operasi berlangsung. Hal ini merupakan tantangan tersendiri karena memerlukan agen sedasi ringan yang tidak menyebabkan ancaman gangguan jalan nafas serta analgetik yang cukup. ${ }^{14}$ Deksmedetomidin merupakan obat golongan agonis $\alpha 2$-adrenergic reseptor yang memiliki efek sedasi tanpa risiko depresi respirasi, pasien mudah dibangunkan dan kooperatif saat operasi.

Deksmedetomidin menginduksi sedasi dengan menurunkan aktivitas neuron noradrenergik di lokus cereuleus di batang otak, sehingga meningkatkan aktivitas inhibisi neuron gamma-aminobutyric acid (GABA) di nucleus preoptic ventrolateral. Deksmedetomidine juga memiliki efek anelgesi. Obat ini biasa digunakan untuk sedasi ringan pada pasien ICU yang akan di ekstubasi, atau untuk mengurangi kebutuhan penggunaan obat opioid karena efeknya yang meningkatkan efek sedasi obat sedasi lainnya bila digunakan bersamaan. ${ }^{15,16}$

\section{Kasus}

\section{Kasus Pertama}

\section{Anamnesis}

Seorang wanita, 46 tahun datang ke rumah sakit dengan keluhan nyeri di punggung menjalar ke kedua pinggang dan kaki sejak tiga bulan yang lalu. Nyeri dirasakan hilang timbul, paling nyeri saat bangun tidur dan berkurang bila tidur terlentang. Kedua kaki terasa kebas sejak satu bulan yang lalu, masih bisa digerakkan dan berjalan. Pasien sudah berobat ke dokter penyakit dalam dan dokter spesialis saraf, rutin minum obat, nama obat tidak tahu, nyeri hilang lalu timbul lagi, kebas tetap. Pasien tidak memiliki riwayat darah tinggi, kencing manis, penyakit jantung. Pasien belum pernah operasi sebelumnya. Keluarga pasien tidak ada yang memiliki riwayat penyakit seperti ini.

\section{Pemeriksaan Fisik}

Setelah dilakukan pemeriksaan fisik, didapatkan data pasien kondisi umum baik, kesadaran compos mentis, tidak ada demam, batuk pilek maupun sesak. Tekanan darah 110/70 $\mathrm{mmHg}$, denyut nadi 90x/menit, laju nafas $18 x /$ menit, suhu $36,7^{\circ} \mathrm{C}$, berat badan 75 kilogram dan tinggi badan $150 \mathrm{~cm}$. GCS E4M5V6. Mata tidak ada 
konjungtiva anemis, jantung dan paru dalam batas normal, motorik ekstremitas dalam batas normal. Pemeriksaan EKG didapat hasil normo sinus ritme. Pemeriksaan rontgen foto thoraks didapatkan jantung dan pulmo tidak ada

\section{Pemeriksaan Penunjang}

Tabel 1. Hasil pemeriksaan laboratorium pasien pertama

\begin{tabular}{lll}
\hline Pemeriksaan & Hasil & Nilai Normal \\
Hemoglobin & $13,7 \mathrm{~g} / \mathrm{dL}$ & $12,0-15,0$ \\
Hematokrit & $39,3 \%$ & $35-47$ \\
Leukosit & $8.700 / \mu \mathrm{L}$ & $5-13,5$ \\
Trombosit & $432.000 / \mu \mathrm{L}$ & $150-450$ \\
Natrium & 136 & $136-145$ \\
Kalium & 4,0 & $3,5-5,1$ \\
Clorida & 102 & $98-107$ \\
PPT/K & $11,7 / 11,9$ & $9,4-11,3$ \\
PTT/K & $28,4 / 32,3$ & $27,7-40,2$ \\
\hline
\end{tabular}

kelainan. Pemeriksaan MRI lumbal didapat hasil protrusio posterocentral posterolateral kanan kiri diskus invertebralis L4-5 dan bulging posterocentral posterolateral kanan kiri disertai pendesakan thecal sac dan penyempitan foramen neuralis kanan kiri setinggi level tersebut, facet joint effusion kanan vertebra L5-S1 dan

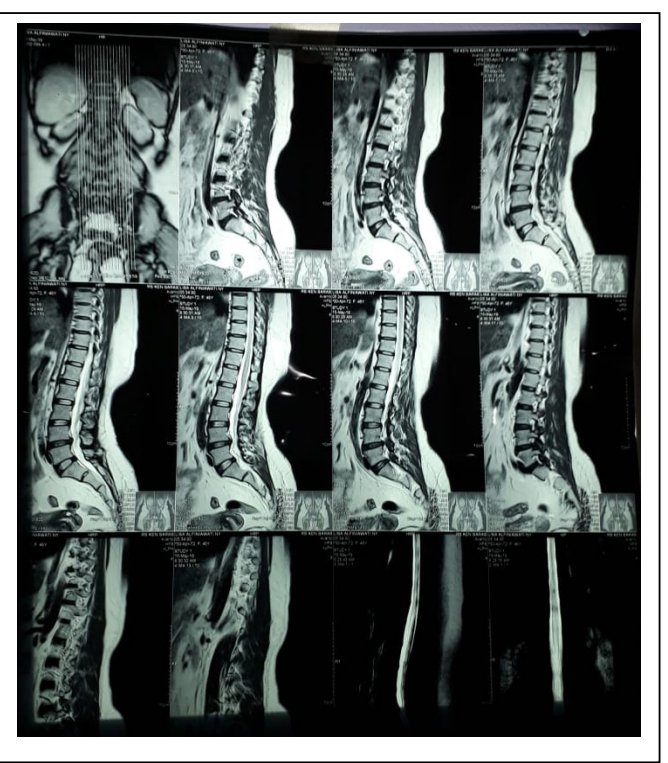

Gambar 1. MRI Lumbosacral Tanpa Kontras Pasien Pertama penebalan ligamentum flavum setinggi L4-5.

\section{Pengelolaan Anestesi}

Saat kunjungan pre operatif pasien dijelaskan bahwa saat operasi pasien akan diposisikan tengkurap, dimasukkan obat sehingga merasa mengantuk, akan dibangunkan di tengah operasi untuk diberi pertanyaan dan akan terasa kurang nyaman selama operasi karena posisi tengkurap. Setelah diberikan penjelasan, pasien setuju untuk dilakukan tindakan perasi. Persiapan preoperatif yang dilakukan adalah dengan pemberian premedikasi midazolam $5 \mathrm{mg}$ dan fentanyl $100 \mathrm{mcg}$ intravena setelah posisi pasien tengkurap. Karena kendala waktu, loading dose deksmedetomidine $50 \mathrm{mcg}(1 \mathrm{mcg} / \mathrm{kgBB}$ syringe pump), diberikan 5 menit sebelum operasi saat operator mempersiapkan area operasi pada punggung pasien. Saat dimulai irisan, pasien diberikan fentanyl $50 \mathrm{mcg}$ intravena. Setelah 10 menit, loading dose deksmedetomidine diganti dengan dosis pemeliharaan $(0,2-1 \mathrm{mcg} / \mathrm{kg} / \mathrm{jam})$ sejumlah $45 \mathrm{mcg} / \mathrm{jam}$ dengan syringe pump. Dosis ini dapat dinaikkan hingga $75 \mathrm{mcg} / \mathrm{jam}$ bila pasien masih bangun.Pemantauan yang dilakukan adalah tekanan darah, detak jantung, laju pernafasan dan derajat nyeri pasien (dengan Visual Analog Scale/VAS). Secara berkala pasien dibangunkan untuk ditanyai apakah nyeri atau tidak. Selama operasi, tercatat pasien terbangun dan merasakan nyeri hingga lima kali (VAS > 8). Pasien terbangun dan merasa nyeri tiap dilakukan manuver seperti penusukan jarum penanda, saat trokar dimasukkan dan disektomi saraf. Tiap kali pasien terbangun dan merasa nyeri, diberikan bolus fentanyl $50 \mathrm{mcg}$ dan midazolam $2 \mathrm{mg}$ intravena. Total fentanyl tambahan yang diberikan sejumlah $200 \mathrm{mcg}$ dan midazolam 8 $\mathrm{mg}$. Setelah pemberian midazolam yang terakhir, pasien sulit dibangunkan, tidak dapat ditanyai mengenai nyeri saat dilakukan tindakan.

\section{Pengelolaan Pascabedah}

Operasi berlangsung selama 90 menit. Setelah selesai operasi, pasien sulit dibangunkan, sehingga perlu menunggu 10 menit hingga pasien sadar penuh dan dapat pindah tempat tidur sendiri. Kondisi setelah operasi, pasien sadar penuh, tekanan darah 130/64 $\mathrm{mmHg}$, 
Tabel 4. Pemantauan yang Dilakukan selama Operasi Berlangsung (Kasus 2)

\begin{tabular}{|c|c|c|c|c|c|c|c|c|c|}
\hline $\begin{array}{l}\text { Tanda } \\
\text { Vital }\end{array}$ & 08.00 & 08.15 & 08.30 & 08.45 & 09.00 & 09.15 & 09.30 & 09.45 & 10.00 \\
\hline $\mathrm{KU}$ & $\begin{array}{l}\text { Terse- } \\
\text { dasi }\end{array}$ & Tersedasi & $\begin{array}{l}\text { Terse- } \\
\text { dasi } \\
\end{array}$ & $\begin{array}{l}\text { Terse- } \\
\text { dasi }\end{array}$ & Bangun & $\begin{array}{l}\text { Terse- } \\
\text { dasi }\end{array}$ & $\begin{array}{l}\text { Terse- } \\
\text { dasi } \\
\end{array}$ & $\begin{array}{l}\text { Terse- } \\
\text { dasi } \\
\end{array}$ & Bang-un \\
\hline $\begin{array}{l}\text { TD } \\
(\mathrm{mmHg}) \\
\mathrm{T}(\mathrm{mmHg}\end{array}$ & $107 / 64$ & $96 / 60$ & $92 / 65$ & $95 / 70$ & $138 / 86$ & $117 / 82$ & $94 / 62$ & $109 / 72$ & $118 / 82$ \\
\hline $\begin{array}{l}\text { HR (kali/ } \\
\text { mnt }\end{array}$ & 64 & 66 & 62 & 68 & 93 & 74 & 73 & 75 & 82 \\
\hline $\begin{array}{l}\text { RR (kali/ } \\
\text { mnt) }\end{array}$ & 12 & 12 & 12 & 14 & 18 & 14 & 12 & 12 & 14 \\
\hline VAS & 2 & 2 & 2 & 2 & 8 & 5 & 2 & 2 & 2 \\
\hline Terapi & $\begin{array}{l}\text { dexme- } \\
\text { detomi- } \\
\text { dine } 35 \\
\text { mcg/jam } \\
\text { SP }\end{array}$ & & $\begin{array}{l}\text { Injeksi } \\
\text { fentanyl } \\
25 \mathrm{mcg} \\
\text { iv }\end{array}$ & & $\begin{array}{l}\text { dexmed } \\
11 \mathrm{mcg} / \\
\text { jam SP } \\
\text { Injeksi } \\
\text { midazol- } \\
\text { am } 2 \mathrm{mg} \text {, } \\
\text { fen- } \\
\text { tanyl } 50 \\
\text { mcg iv }\end{array}$ & & $\begin{array}{l}\text { Injeksi } \\
\text { Fentanyl } \\
25 \mathrm{mcg} \\
\text { iv }\end{array}$ & $\begin{array}{l}\text { dexmed } \\
\text { stop }\end{array}$ & \\
\hline $\begin{array}{l}\text { Keteran- } \\
\text { gan }\end{array}$ & $\begin{array}{l}\text { Operator } \\
\text { memulai } \\
\text { insisi }\end{array}$ & $\begin{array}{l}\text { Operator } \\
\text { menusuk- } \\
\text { kan jarum } \\
\text { penanda }\end{array}$ & $\begin{array}{l}\text { Operator } \\
\text { mema- } \\
\text { sukkan } \\
\text { trokar }\end{array}$ & & $\begin{array}{l}\text { Operator } \\
\text { disekto- } \\
\text { mi saraf, } \\
\text { menguji } \\
\text { moto- } \\
\text { rik dan } \\
\text { sensorik } \\
\text { pasien }\end{array}$ & & & & $\begin{array}{l}\text { operasi } \\
\text { selesai }\end{array}$ \\
\hline
\end{tabular}

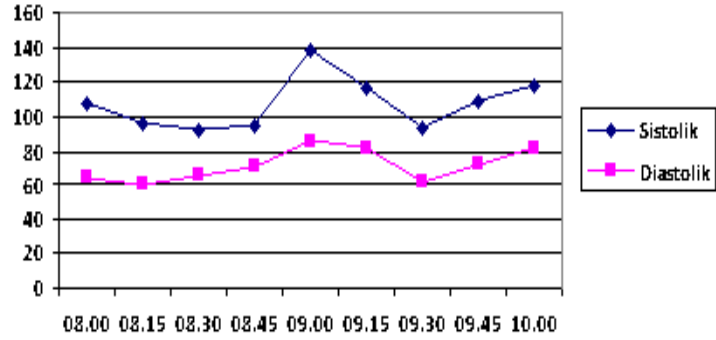

\section{Grafik 3. Tekanan Darah Pasien Kedua selama} Operasi

denyut jantung $88 \mathrm{x} /$ menit, laju nafas $12 \mathrm{x} /$ menit dengan VAS 6. Setelah operasi, pasien kembali ke ruangan. Sehari setelah operasi, pasien kembali ditanya perihal nyeri selama operasi.

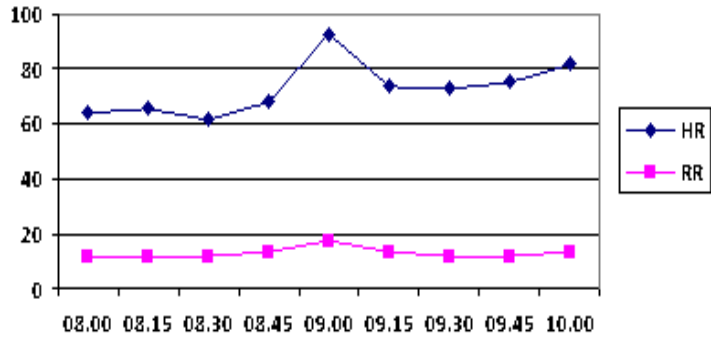

Grafik 4. Laju Jantung dan Nafas Pasien Kedua selama Operasi

Pasien mengatakan selama operasi kurang nyaman karena masih bisa merasa nyeri sekali, lalu posisi juga membuat tangan pasien pegal, nyeri dan rasa kebas di kedua kaki masih ada 
hingga sehari paska operasi, dengan VAS 4.

\section{Kasus Kedua}

\section{Anamnesis}

Seorang wanita, 40 tahun, datang dengan keluhan nyeri menjalar dari pinggang kanan hingga telapak kaki kanan sejak satu tahun yang lalu. Nyeri hilang timbul, dirasakan paling berat bila sedang beraktifitas dan berkurang bila kaki diluruskan posisi duduk atau tidur. Kedua kaki masih bisa digerakkan dan jalan seperti biasa. Pasien sudah berobat ke dokter spesialis saraf selama 3 bulan, rutin minum obat penghilang rasa nyeri tapi nyeri masih timbul. Pasien lalu dirujuk ke dokter bedah saraf, dilakukan operasi laminektomi satu kali dengan general anestesi. Setelah operasi, pasien merasa nyeri hilang dan bisa beraktifitas seperti biasa. 3 bulan setelah operasi, pasien merasakan nyeri hilang timbul lagi, sama seperti sebelum operasi. Satu bulan yang lalu pasien periksa ke dokter saraf, dilakukan tindakan penyuntikan tetapi pasien merasa sangat kesakitan,tidak jadi dilakukan penyuntikan sehingga dikonsulkan ke dokter spesialis bedah saraf untuk dilakukan operasi. Pasien tidak memiliki riwayat darah tinggi, kencing manis, penyakit jantung. Pasien sudah pernah operasi sebelumnya. Keluarga pasien tidak ada yang memiliki riwayat penyakit seperti ini.

\section{Pemeriksaan Fisik}

Setelah dilakukan pemeriksaan fisik, didapatkan data pasien kondisi umum baik, kesadaran compos mentis, tidak ada demam, batuk pilek maupun sesak, tekanan darah 100/70 $\mathrm{mmHg}$, denyut nadi $86 x /$ menit, laju nafas $14 x /$ menit, suhu $36,5 \mathrm{oC}$, berat badan 55 kilogram dan tinggi badan $150 \mathrm{~cm}$. GCS E4M5V6. Pemeriksaan fisik meliputi mata tidak ada konjungtiva anemis, jantung dan paru dalam batas normal, motorik ekstremitas dalam batas normal.

\section{Pemeriksaan Penunjang}

Pemeriksaan EKG didapat hasil normo sinus ritme. Pemeriksaan $\mathrm{X}$ foto toraks didapatkan jantung dan paru tidak ada kelainan. Pemeriksaan MRI lumbal didapat hasil spondilolistesis
Tabel 3. Hasil Pemeriksaan Laboratorium Pasien Kedua

\begin{tabular}{lll}
\hline Pemeriksaan & Hasil & Nilai Normal \\
\hline Hemoglobin & $12,4 \mathrm{~g} / \mathrm{dL}$ & $12,0-15,0$ \\
Hematokrit & $35,3 \%$ & $35-47$ \\
Leukosit & $7.100 / \mu \mathrm{L}$ & $5-13,5$ \\
Trombosit & $274.000 / \mu \mathrm{L}$ & $150-450$ \\
Natrium & 140 & $136-145$ \\
Kalium & 3,8 & $3,5-5,1$ \\
Clorida & 100 & $98-107$ \\
PPT/K & $10,5 / 11,2$ & $9,4-11,3$ \\
PTT/K & $32,4 / 35,6$ & $27,7-40,2$ \\
\hline
\end{tabular}

posterior vertebra $\mathrm{C} 4$ dan $\mathrm{C} 5$, spondylosis cervicothoracolumbalis, kompresi vertebra C5 (derajat 1), endplate changes pada endplate superior L2 (modic type 2), degenerative disc pada C3-4, C4-5, C5-6 dan C6-7 dan L4-5, bulging posterocentral discus intervertebralis $\mathrm{C} 4-5$ dan C5-6, C6-7 dan Th1-2 disertai pendesakan thecal sac, protusio posterocentral dan posterolateral kanan kiri pada discus intervertebralis L5-S1 disertai obliterasi foramen neuralis kanan kiri, penebalan ligamentum flavum kanan kiri setinggi L4-5 dan L5-S1.

Pengelolaan Anestesi

Saat kunjungan pre operatif pasien dijelaskan

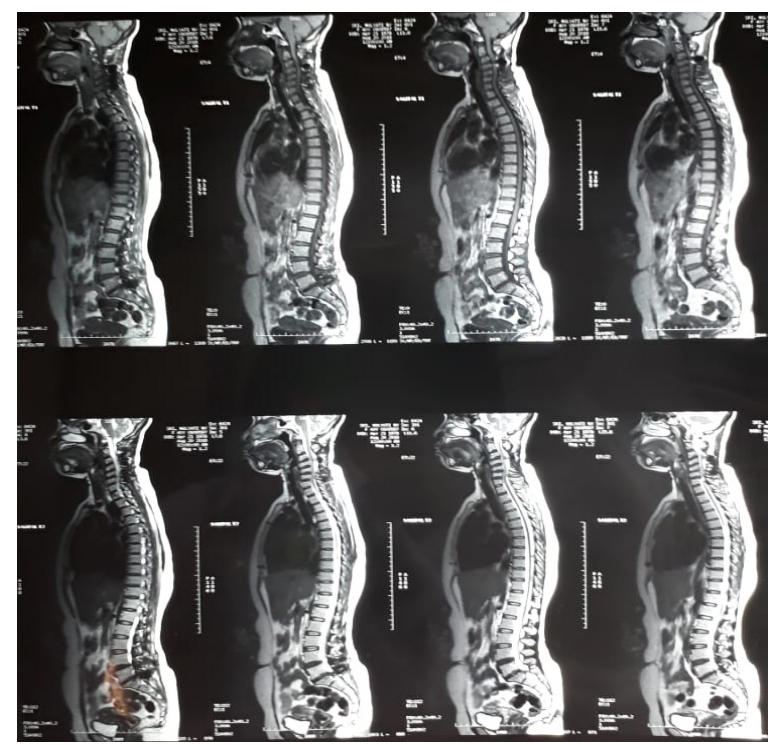

Gambar 2. MRI Wholespine Pasien Kedua 
bahwa saat operasi pasien akan diposisikan tengkurap, dimasukkan obat sehingga merasa mengantuk, akan dibangunkan di tengah operasi untuk diberi pertanyaan dan akan terasa kurang nyaman selama operasi karena posisi tengkurap. Setelah diberikan penjelasan, pasien setuju untuk dilakukan tindakan operasi. Persiapan preoperatif yang dilakukan adalah dengan pemberian premedikasi midazolam 5 $\mathrm{mg}$ dan fentanyl $100 \mathrm{mcg}$ intravena setelah posisi pasien telungkup. Loading dose deksmedetomidine $(1 \mathrm{mcg} / \mathrm{kgBB})$ diberikan 55

Tabel 4. Pemantauan yang Dilakukan selama Operasi Berlangsung (Kasus 2)

\begin{tabular}{|c|c|c|c|c|c|c|c|c|c|}
\hline $\begin{array}{l}\text { Tanda } \\
\text { Vital }\end{array}$ & 08.00 & 08.15 & 08.30 & 08.45 & 09.00 & 09.15 & 09.30 & 09.45 & 10.00 \\
\hline KU & $\begin{array}{l}\text { Terse- } \\
\text { dasi }\end{array}$ & Tersedasi & $\begin{array}{l}\text { Terse- } \\
\text { dasi }\end{array}$ & $\begin{array}{l}\text { Terse- } \\
\text { dasi }\end{array}$ & Bangun & $\begin{array}{l}\text { Terse- } \\
\text { dasi }\end{array}$ & $\begin{array}{l}\text { Terse- } \\
\text { dasi }\end{array}$ & $\begin{array}{l}\text { Terse- } \\
\text { dasi }\end{array}$ & Bang-un \\
\hline $\begin{array}{l}\text { TD } \\
(\mathrm{mmHg})\end{array}$ & $107 / 64$ & $96 / 60$ & $92 / 65$ & $95 / 70$ & $138 / 86$ & $117 / 82$ & $94 / 62$ & $109 / 72$ & $118 / 82$ \\
\hline $\begin{array}{l}\text { HR (kali/ } \\
\text { mnt) }\end{array}$ & 64 & 66 & 62 & 68 & 93 & 74 & 73 & 75 & 82 \\
\hline $\begin{array}{l}\text { RR (kali/ } \\
\text { mnt) }\end{array}$ & 12 & 12 & 12 & 14 & 18 & 14 & 12 & 12 & 14 \\
\hline VAS & 2 & 2 & 2 & 2 & 8 & 5 & 2 & 2 & 2 \\
\hline Terapi & $\begin{array}{l}\text { dexme- } \\
\text { detomi- } \\
\text { dine } 35 \\
\text { mcg/jam } \\
\text { SP }\end{array}$ & & $\begin{array}{l}\text { Injeksi } \\
\text { fentanyl } \\
25 \mathrm{mcg} \\
\text { iv }\end{array}$ & & $\begin{array}{l}\text { dexmed } \\
11 \mathrm{mcg} / \\
\text { jam SP } \\
\text { Injeksi } \\
\text { midazol- } \\
\text { am 2mg, } \\
\text { fen- } \\
\text { tanyl } 50 \\
\text { mcg iv }\end{array}$ & & $\begin{array}{l}\text { Injeksi } \\
\text { Fentanyl } \\
25 \mathrm{mcg} \\
\text { iv }\end{array}$ & $\begin{array}{l}\text { dexmed } \\
\text { stop }\end{array}$ & \\
\hline $\begin{array}{l}\text { Keteran- } \\
\text { gan }\end{array}$ & $\begin{array}{l}\text { Operator } \\
\text { memulai } \\
\text { insisi }\end{array}$ & $\begin{array}{l}\text { Operator } \\
\text { menusuk- } \\
\text { kan jarum } \\
\text { penanda }\end{array}$ & $\begin{array}{l}\text { Operator } \\
\text { mema- } \\
\text { sukkan } \\
\text { trokar }\end{array}$ & & $\begin{array}{l}\text { Operator } \\
\text { disekto- } \\
\text { mi saraf, } \\
\text { menguji } \\
\text { moto- } \\
\text { rik dan } \\
\text { sensorik } \\
\text { pasien }\end{array}$ & & & & $\begin{array}{l}\text { operasi } \\
\text { selesai }\end{array}$ \\
\hline
\end{tabular}

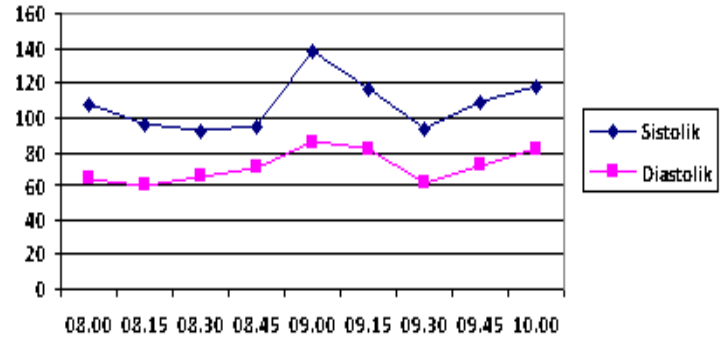

Grafik 3. Tekanan Darah Pasien Kedua selama Operasi

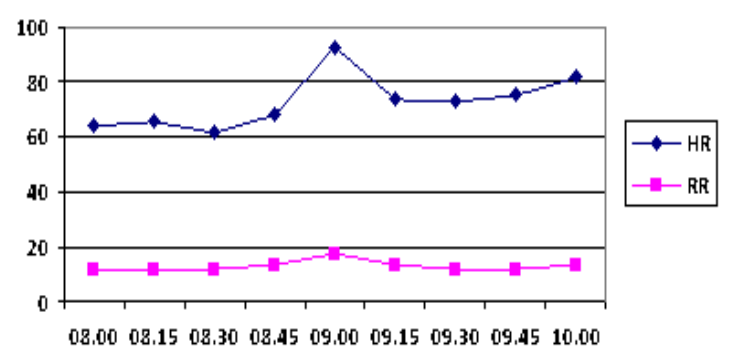

Grafik 4. Laju Jantung dan Nafas Pasien Kedua selama Operasi 
mcg habis dalam 10 menit dengan syringe pump sebelum operasi dimulai. Saat dimulai irisan, pasien diberikan fentanyl $50 \mathrm{mcg}$. Setelah 10 menit, loading dose deksmedetomidine diganti dengan dosis pemeliharaan $(0,2-1 \mathrm{mcg} / \mathrm{kg} / \mathrm{jam})$ sebanyak $35 \mathrm{mcg} / \mathrm{jam}$ dengan syringe pump. Dosis ini dapat dinaikkan hingga $50 \mathrm{mcg} / \mathrm{jam}$ bila pasien masih bangun. Pemantauan yang dilakukan adalah tekanan darah, detak jantung, laju pernafasan dan VAS pasien. Secara berkala pasien dibangunkan untuk ditanyai apakah nyeri atau tidak. Selama operasi, tercatat pasien terbangun dan merasakan nyeri hingga lima kali (VAS >8). Apabila pasien terbangun diberikan midazolam $2 \mathrm{mg}$. Sedangkan pemberian fentanyl secara intermiten $25 \mathrm{mcg}$ intravena tiap 30 menit. Pasien terbangun dan merasa nyeri hanya saat trokar dimasukkan. Total fentanyl tambahan yang diberikan sejumlah $100 \mathrm{mcg}$ dan midazolam 2 mg. Selama operasi, pasien kooperatif tiap kali dibangunkan untuk ditanyai nyeri atau tidak. Pasien juga mampu menggerakkan kaki kanannya saat diminta oleh operator. Tidak ada kendala jalan nafas selama operasi.

\section{Pengelolaan Pascabedah}

Operasi berlangsung selama 120 menit. Setelah operasi selesai, pasien mudah dibangunkan. Pasien sadar penuh dan dapat pindah tempat tidur sendiri. Kondisi setelah operasi, pasien sadar penuh, tekanan darah 110/74 $\mathrm{mmHg}$, denyut jantung $72 \mathrm{x} /$ menit, laju nafas $12 \mathrm{x} /$ menit dengan VAS 2. Setelah operasi, pasien kembali ke ruangan. Sehari setelah operasi, pasien kembali ditanya perihal rasa nyeri selama operasi. Pasien mengatakan tidak ingat tindakan atau nyeri yang dirasakan selama operasi. Setelah operasi, pasien tidak merasakan nyeri tetapi kaki kanannya terasa lemah tidak dapat digunakan untuk berjalan. Pasien juga merasa nyaman saat operasi serta tidak merasa pegal di area bahu dan tangan, VAS pada derajat 2 .

\section{Pembahasan}

Salah satu tatalaksana pasien dengan lumbar spinal stenosis adalah endoskopi disektomi. Teknik anestesi yang dipilih adalah awake anastesi, menggunakan sedasi ringan dan analgetik adekuat, diharapkan pasien tidur tapi bisa dibangunkan sewaktu dibutuhkan. Dibutuhkan kerjasama yang baik antara dokter bedah saraf dan dokter anestesi untuk menghindari kejadian tak diinginkan dan menjamin kenyamanan pasien. Tatalaksana perioperatif dimulai sejak kunjungan pra anestesi, premedikasi, induksi, pemantauan selama operasi dan pemantauan pasca operasi. ${ }^{8-9}$ Pemilihan awake anestesi memiliki risiko gangguan jalur nafas karena posisi pasien telungkup, sehingga rawan terjadi penutupan jalur nafas dan kesulitan manuver membuka jalan nafas. ${ }^{15}$ Cara untuk menurunkan kemungkinan terjadinya gangguan jalan nafas adalah dengan menggunakan obat yang tidak memiliki efek depresi nafas. Dipilihlah deksemedetomidine yang merupakan obat golongan agonis $\alpha 2$-adrenergic reseptor yang memiliki efek sedasi tanpa risiko depresi respirasi serta memiliki efek analgesi sehingga menurunkan kebutuhan penggunaan opioid. ${ }^{16-17}$ Akan tetapi penggunaan deksemedetomidin tidak dapat sendirian, perlu diberikan obat sedasi dan analgetik. Midazolam sebagai obat sedasi yang memiliki efek sinergis dengan deksmedetomine. Fentanyl sebagai opioid sedang dipilih karena onsetnya yang cepat sehingga bisa bekerja langsung saat pasien nyeri. ${ }^{18-17}$

Berdasarkan kasus pertama dan kedua yang samasama menjalani operasi endoskopi disektomi karena lumbar spinal stenosis akibathernia nucleus pulposus di Vertebra L4-5, dilakukan dua cara berbeda dalam penggunaan deksmedetomidine serta ajuvannya. Pasien pertama mendapat loading dose dexmedetomidine selagi dilakukan irisan, sedangkan pada pasien kedua dimasukkan loading dose dexmedetomidine tepat 10 menit sebelum dilakukan irisan. Hal ini berpengaruh pada waktu pemberian dosis pemeliharaan pada pasien pertama yang agak terlambat dan riwayat pasien pernah menjalani operasi sebelumnya sehingga pasien belum mencapai onset deksmedetomidine yang diperlukan. Pasien pertama sering terbangun meski dosis pemeliharaan deksmedetomidine yang diberikan sudah maksimal ditambah penggunaan ajuvan midazolam dan fentanyl dalam dosis yang lebih besar dan jangka waktu lebih sering, mengingat pasien pertama pernah menjalani tindakan 
operasi dengan general anestesi sehingga berbeda dengan pasien kedua. Perbedaan cara pemberian fentanyl juga berpengaruh.

Pada pasien pertama, pemberian fentanyl hanya saat pasien sakit sedangkan pada pasien kedua, pemberian fentanyl tiap 30 menit, menyesuaikan durasi kerja fentanyl. Hal ini terbukti mampu menjaga pasien tidak nyeri dan secara langsung berperan supaya pasien tidak bangun. Efek anestesi paska operasi juga berbeda. Pada kedua pasien tidak didapatkan keluhan mual, muntah setelah sadar. Akan tetapi pasien pertama merasa nyeri setelah operasi bisa diakibatkan karena riwayat operasi dengan anestesi umum sehingga sedasi dan analgetik yang diberikan dengan anestesi awake kurang adekuat, sehingga pasien terbangun di tengah operasi dan terjadi perubahan posisi yang membuat pasien tidak nyaman. Sedangkan pada pasien yang kedua, efek amnesia anterograde dari midazolam membuat pasien lupa yang terjadi saat operasi. Pasien kedua tidak merasa nyeri di area operasi.

\section{Simpulan}

Lumbar spinal stenosis (LSS) merupakan kumpulan gejala penyakit yang berhubungan dengan berkurangnya ukuran kanalis spinalis vertebra lumbal sehingga menyebabkan penekanan saraf yang terletak di dalamnya. Kasus LSS dapat terjadi karena proses kongenital atau degeneratif. Salah satu tatalaksana LSS dapat dilakukan dengan awake endospine disektomi. Kunjungan praanestesi, pemantauan selama dan paska operasi, pemilihan obat sedasi dan analgetik serta waktu pemberian yang tepat harus dilakukan untuk menjamin awake endospine disektomi yang aman dan nyaman. Deksmedetomidine yang merupakan obat golongan agonis $\alpha 2$-adrenergic reseptor yang memiliki efek sedasi tanpa risiko depresi respirasi serta memiliki efek analgesi dapat digunakan untuk metode awake endospine disektomi ini.

\section{Daftar Pustaka}

1. Ciricillo SF, Weinstein PR. Lumbar spinal stenosis. West J Med 1993 Feb;158(2):171-7.

2. Amundsen T, Weber H, Lilleas F, Nordal HJ, Abdelnoor M, Magnaes B. Lumbar spinal stenosis. Clinical and radiologic features. Spine 1995 May 15;20(10):1178-86.

3. Johnsson KE, Rosen I, Uden A. The natural course of lumbar spinal stenosis. Clin Orthop Relat Res 1992 Jun;279:82-6.

4. Herno A. Spinal Stenosis without deformity: Nonoperative treatment. In: Herkowitz $\mathrm{HH}$, Dvorak JJ., Bell G, Nordin M, Grob DD, editors. The Lumbar Spine. Philadelphia: Lippincott Williams \& Wilkins; 2004, 490-4.

5. Sairyo K, Biyani A, Goel V, Leaman D, Booth R Jr, Thomas J, et al. Pathomechanism of ligamentum flavum hypertrophy: a multidisciplinary investigation based on clinical, biomechanical, histologic, and biologic assessments. Spine 2005 Dec $1 ; 30(23): 2649-56$.

6. Jenis LG, An HS. Spine update. Lumbar foraminal stenosis. Spine 2000;25(3):38994.

7. Dorland WAN. Kamus Saku Kedokteran Dorland Edisi Bahasa Indonesia. Jakarta: Penerbit Buku Kedokteran EGC;2011, 5053.

8. Company Saunder. B. W. Classification, diagnostic imaging, and imaging characterization of a lumbar. Volume 38. 200 4.

9. Wirawan. Nyeri Pinggang. Dalam: Nyeri : Pengenalan dan Tatalaksana. Semarang: Badan Penerbit Universitas Diponegoro; 1996:93-99

10. Matsumoto M, Watanabe K, Tsuji T, Ishii K, Takaishi H, Nakamura M, et al. Nocturnal leg cramps: a common complaint in patients with lumbar spinal canal stenosis. Spine 2009 Mar 1;34(5):E189- 94. 
11. Inui Y, Doita M, Ouchi K, Tsukuda M, Fujita N, Kurosaka M. Clinical and radiologic features of lumbar spinal stenosis and disc herniation with neuropathic bladder. Spine 2004 Apr 15;29(8):869-73.

12. Eskola A, Pohjolainen T, Alaranta H, Soini J, Tallroth K, Slatis P. Calcitonin treatment in lumbar spinal stenosis: a randomized, placebo-controlled, double-blind, cross-over study with one-year follow-up. Calcif Tissue Int 1992 May;50(5):400-3.

13. Podichetty VK, Segal AM, Lieber M, Mazanec DJ. Effectiveness of salmon calcitonin nasal spray in the treatment of lumbar canal stenosis: a double-blind, randomized, placebo-controlled, parallel group trial. Spine 2004 Nov 1;29(21):23439.
14. Tafazal SI, Ng L, Sell P. Randomised placebo-controlled trial on the effectiveness of nasal salmon calcitonin in the treatment of lumbar spinal stenosis. Eur Spine J 2007 Feb;16(2):207-12.

15. John FB, David CM, John DW. Morgan \& Mikhail's Clinical Anesthesiology 5th edition. New York. Mc-Graw Hill Education. 2013

16. Cormack JR, Orme RM,Costello TG. "The role of alpha2-agonists in neurosurgery". Journal of Clinical Neuroscience. 2005; 12 (4): $375-8$.

17. Laura P, Teresa G, Paolo F, Giovanni L, Gabriele F, Alberto Z. Dexmedetomidine as a sedative agent in critically ill patients: a meta-analysis of randomized controlled trials. PLOS ONE. 8(12):e82913 